\title{
Comparison of microbiological assay and HPLC-UV for determination of fluconazole in capsules
}

\author{
Kelly Marques Queiroz', Maria-Luiza Martins Silva ${ }^{1}$, Nathália Duque Prado ${ }^{1}$, Paulo Marcelo \\ Andrade Lima ${ }^{1}$, Rosiane Dias Lopes Diniz ${ }^{1}$, Isabela Costa César ${ }^{2}$, Gerson Antônio Pianetti², \\ Daniel Assis Santos ${ }^{1 *}$
}

\author{
${ }^{1}$ Laboratório de Microbiologia, Faculdade de Ciências da Saúde, Universidade Vale do Rio Doce, ${ }^{2}$ Departamento de Produtos \\ Farmacêuticos, Faculdade de Farmácia, Universidade Federal de Minas Gerais
}

\begin{abstract}
The development of a specific agar diffusion bioassay for the quantitative determination of fluconazole formulated in capsules was carried out using a strain of Candida albicans ATCC 18804 as the test organism. A prospective validation of the method showed adequate linearity $\left(r^{2}=0.9995\right)$, precision (R.S.D. $=4.0 \%$ for intra-day and $4.5 \%$ for inter-day precision) and accuracy (mean recovery $=102.9 \%$ ). High performance liquid chromatography was chosen as a comparison method for the fluconazole determination. The contents of fluconazole determined by both methods, for four capsule samples, showed a strong correlation, confirmed by Pearson's correlation coefficient value $(r=0.9884)$. The bioassay is a suitable method for both research and pharmaceutical industry laboratories.
\end{abstract}

Uniterms: Fluconazole/quantitative determination. Microbiological assay/agar diffusion. High performance liquid chromatography.

\begin{abstract}
Este trabalho visou ao desenvolvimento e validação de um método microbiológico por difusão em ágar para quantificação de fluconazol em cápsulas utilizando o isolado Candida albicans ATCC 18804 como reagente biológico. O método foi validado e foi verificada linearidade $\left(\mathrm{r}^{2}=0,9995\right)$, precisão (D.P.R. $=4.0 \%$ para precisão intra-dia e 4,5\% para precisão inter-dia) e exatidão (recuperação média =102,9\%). Concomitantemente, foi realizado o doseamento de fluconazol nas cápsulas por meio de cromatografia líquida de alta eficiência. Os teores encontrados por ambos os métodos demonstraram alta correlação, confirmada pelo Coeficiente de Correlação de Pearson ( $\mathrm{r}=0,9884)$. O ensaio microbiológico desenvolvido pode ser considerado ferramenta valiosa tanto para a pesquisa científica quanto para a rotina da indústria farmacêutica.
\end{abstract}

Unitermos: Fluconazol/quantificação. Ensaio microbiológico/por difusão em ágar. Cromatografia líquida de alta eficiência.

\section{INTRODUCTION}

Fluconazole, a triazole agent, is one of the most commonly prescribed systemic antifungals (Koks et al., 1996; Marchetti et al., 2001; Kim et al., 2007). It is well absorbed after oral administration and shows good penetration into cerebrospinal fluid (Harris et al., 1999). This agent is used in the treatment of oropharyngeal, esophageal, or vulvovaginal candidiasis, as well as other serious systemic candida infections. It is also used for

*Correspondence: D. A. Santos. Laboratório de Microbiologia, Faculdade de Ciências da Saúde, Universidade Vale do Rio Doce, Rua Israel Pinheiro, 2000 - Bairro Universitário, 35020-220 - Governador Valadares - MG, Brasil. E-mail: danielsantosassis@yahoo.com.br the treatment of meningitis caused by Cryptococcus $\mathrm{sp}$. (Mathy et al., 2003; Porta et al., 2005). Fluconazole is available commercially for oral administration in capsules of 50,150 and $200 \mathrm{mg}$. A sodium chloride solution of this agent for intravenous administration is also available (Porta et al., 2005).

The use of this drug is widespread around the world, as the pharmaceutical industry and even compounding pharmacies produce the capsules for human usage. It is important to mention that capsules with dosage lower than that recommended are ineffective and compromise patient health. Studies focused on fluconazole determination in pharmaceutical formulation by bioassay are scarce, where the majority of papers are related to its study in clinical 
samples using a HPLC method (blood, serum, saliva or skin) (Harris et al., 1989; Rex et al., 1991; GarciaHermoso et al., 1995; Koks et al., 1996; Hülsewede and Dermoumi, 1996; Cohen et al., 1997; Moraes et al., 1999; Abdel-Moety et al., 2002; Mathy et al., 2003; Marchetti et al., 2003; Porta et al., 2005; Kim et al., 2007; Lima et al., 2009).

The most commonly described assay for fluconazole content in capsules are high performance liquid chromatography (HPLC), gas liquid chromatography and spectrophotometry (Harris et al., 1989; Rex et al., 1991; Moraes et al., 1999; Porta et al., 2005; Kim et al., 2007). These methods require expensive equipment and considerable technician time (Rex et al., 1991). Furthermore, fluconazole, as with other antibiotics, may be also quantified by bioassay for its activity assessment (Puranjoti et al., 1999; Porta et al., 2005), but experimental conditions such as concentrations of the inocula, incubation temperature and test microorganism are not yet well established official methods.

Previous studies focusing on fluconazole bioassay development presented methods used for determination of the antifungal levels in plasma, serum (Rex et al., 1991; Porta et al., 2005) and saliva (Koks et al., 1996). Studies of fluconazole determination in pharmaceutical capsules have used mainly HPLC and UV (Abdel-Moety et al., 2002; Porta et al., 2005; Kim et al., 2007), while microbiological method use is scarce. This assay can reveal subtle changes not demonstrable by chemical methods. Moreover, it gives the possibility to evaluate the potency of fluconazole, which is considered important for the analysis of antibiotics (Salgado et al., 2006).

The purpose of this study was to develop and validate a microbiological method to determine the potency of fluconazole in commercial capsules. The bioassay results were compared to those obtained by HPLC, using the same samples.

\section{MATERIAL AND METHODS}

\section{Reagents and materials}

Fluconazole reference standard was kindly supplied by Pfizer. Fluconazole capsules ( $150 \mathrm{mg}$ ) were obtained from four different compounding pharmacies of Governador Valadares, Minas Gerais State, Brazil. Distilled water purified in a Millipore (Bedford, MA, USA) system was used in the analysis. Acetonitrile (HPLC grade) was purchased from Tedia (Fairfield, OH, USA) and dimethyl sulfoxide (DMSO) (analytical grade) from Synth (Diadema, São Paulo State, Brazil).

\section{Bioassay of fluconazole}

A stock standard solution of $1000 \mu \mathrm{g} / \mathrm{mL}$ was prepared by placing $10 \mathrm{mg}$ of fluconazole reference standard into a flask and diluting in DMSO to a total volume of $10 \mathrm{~mL}$. This solution was further diluted in sterile distilled water to a concentration of $625.00 \mu \mathrm{g} / \mathrm{mL}$, which was used for serial two-fold dilution up to $39.06 \mu \mathrm{g} / \mathrm{mL}$. The standard tested concentrations were $625.00\left(\mathrm{~S}_{1}\right), 312.50$ $\left(\mathrm{S}_{2}\right), 156.25$ (R: reference concentration), $78.13\left(\mathrm{~S}_{4}\right)$ and $39.06\left(\mathrm{~S}_{5}\right) \mu \mathrm{g} / \mathrm{ml}$.

A pool of each sample of fluconazole capsules was made and a stock solution of $1000 \mu \mathrm{g} / \mathrm{mL}$ in DMSO was prepared. This solution was diluted in sterile distilled water to a concentration of $156.25 \mu \mathrm{g} / \mathrm{mL}$ (identical to the standard reference concentration - R). All the fluconazole solutions (standard and test) were prepared immediately before performing the test.

Candida albicans ATCC 18804 was maintained on Sabouraud dextrose slant agar at $4{ }^{\circ} \mathrm{C}$. Prior to use, the microorganism was transferred to Sabouraud dextrose slant agar and incubated for $24 \mathrm{~h}$ at $28^{\circ} \mathrm{C}$. After this period, a small portion of the yeast was transferred to a sterile saline solution $(0.9 \%)$ and the transmittance was adjusted to $85 \%$ at a wavelength of $520 \mathrm{~nm}$, which measured $1-5 \mathrm{x}$ $10^{6} \mathrm{CFU} / \mathrm{mL}$ (Figueiredo et al., 2007). Further dilution of the inocula suspension was made in $15 \mathrm{~mL}$ of Sabouraud dextrose agar melted at $45^{\circ} \mathrm{C}$ to achieve a final concentration of $1-5 \times 10^{5} \mathrm{CFU} / \mathrm{mL}$.

Sterile Petri dishes (100 mm x $20 \mathrm{~mm})$ were used in all microbiological tests. A base layer of Sabouraud dextrose $\operatorname{agar}(8 \mathrm{ml})$ was plated before the test to facilitate the visualization of inhibition zones. After base layer solidification, the next layer, to be used for inoculation, was poured into Petri dishes on top of the base layer. The agar was allowed to gel at room temperature for 10 to $15 \mathrm{~min}$. After solidification, $5 \mathrm{~mm}$-diameter wells were bored at six points for a $5 \mathrm{x} 1$ assay (Figure 1). Five Petri dishes were used for each assay in order to test the reference concentration $(\mathrm{R})$ concomitantly with each standard or sample concentrations. Forty microliters of each standard or test solution were pipetted into individual wells. The plates were incubated at $28^{\circ} \mathrm{C}$ for $24 \mathrm{~h}$. The inhibition zone was measured using calipers. Assay plates were tested in triplicate (corresponding to 15 dishes in each assay), resulting in nine measures of the standards $\mathrm{S}_{1}, \mathrm{~S}_{2}, \mathrm{~S}_{4}$ and $\mathrm{S}_{5}$ and the test sample. The R concentration was tested forty-five times (Figure 1) in order to fit data obtained in all the dishes.

The optimization of the previously mentioned experimental conditions were achieved by testing: (i) incubation time of $24 \mathrm{~h}$ and $36 \mathrm{~h}$; (ii) incubation temperature of 


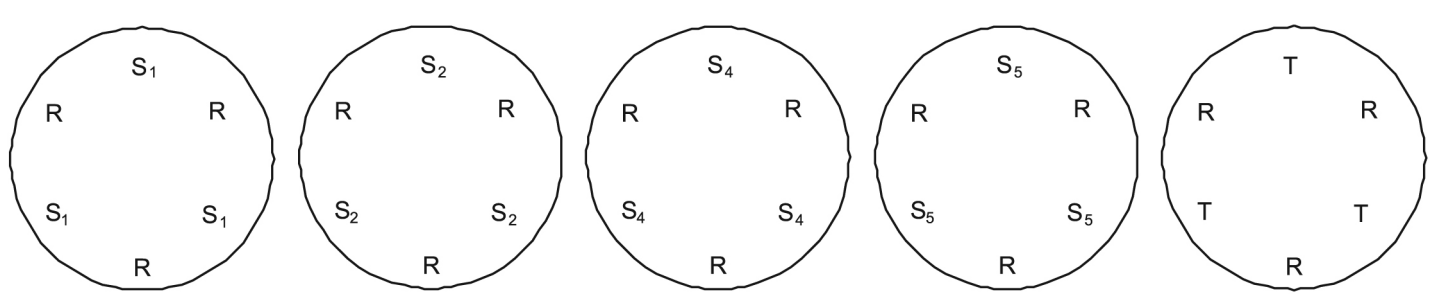

FIGURE 1 - 5 x 1 assay: five Petri dishes were used. The reference concentration (R) was tested concomitantly with all other concentrations. $\mathrm{S}_{1}(625.00 \mu \mathrm{g} / \mathrm{mL}), \mathrm{S}_{2}(312.50 \mu \mathrm{g} / \mathrm{mL}), \mathrm{R}(156.25 \mu \mathrm{g} / \mathrm{mL}), \mathrm{S}_{4}(78.16 \mu \mathrm{g} / \mathrm{mL})$ and $\mathrm{S}_{5}(39.06 \mu \mathrm{g} / \mathrm{mL})$ represent the standard solutions. T represents the sample solution $(156.25 \mu \mathrm{g} / \mathrm{mL})$.

$28^{\circ} \mathrm{C}$ and $37^{\circ} \mathrm{C}$ and (iii) inocula concentration varying from $1-5 \times 10^{3}$ to $1-5 \times 10^{5} \mathrm{CFU} / \mathrm{mL}$.

\section{Correction of the inhibition zone $\left(I Z_{c}\right)$ with the reference $(R)$ concentration}

The average of all measures of $\mathrm{R}$ concentration (in all the dishes) was used to fit the values of inhibition zones in each individual dish.

To fit the obtained data, the following equation was applied:

$\mathrm{IZ}_{\mathrm{c}}=\mathrm{IZ}+\left(\mathrm{R}_{\mathrm{A}}-\mathrm{R}_{\mathrm{s}}\right)$

where: $\mathrm{IZ}_{\mathrm{c}}$ is the value of the corrected inhibition zone; IZ, the average value of the inhibition zone of the standard or tested sample in the studied dish; $\mathrm{R}_{\mathrm{A}}$, the average of the inhibition zone values for the $\mathrm{R}$ concentration in all dishes (a total of 45 values) and $R_{s}$, the average of inhibition zone values for the $\mathrm{R}$ in the studied dish (a total of nine values) (Lima et al., 2009).

The data analysis was made by plotting $\log _{10}$ of fluconazole concentration versus inhibition zones; the curve equation was obtained by regression analysis. Concentrations of test solutions were determined using the curve equation of the standard curve.

\section{Method validation}

The microbiological method was validated by evaluation of linearity, precision and accuracy, according to the procedures described in ICH guidelines Q2 (R1).

(i) Linearity: in order to assess the linearity of the assay, five concentrations of the reference standard were tested $(625.00 ; 312.50 ; 156.25 ; 78.16$ and $39.06 \mu \mathrm{g} / \mathrm{mL})$. A calibration curve for $\log _{10}$ offluconazole concentration versus inhibition zones was plotted and the obtained data were subjected to regression analysis using the Least Squares Method.

(ii) Precision: the intra-day precision was evaluated by analyzing six replicates of fluconazole solutions $(n=6)$, at $100 \%$ of the test concentration $(156.25 \mu \mathrm{g} / \mathrm{mL})$.
Similarly, the inter-day precision was evaluated on two consecutive days $(n=12)$. The concentration of fluconazole in capsule samples was determined and the relative standard deviation (R.S.D.) was calculated.

(iii) Accuracy: this was determined by adding known amounts of fluconazole reference standard (39.06, 117.18 or $195.30 \mu \mathrm{g} / \mathrm{mL})$ to a sample solution $(39.06 \mu \mathrm{g} / \mathrm{mL})$ at the beginning of the analyses, corresponding to 50,100 and $150 \%$ of the test concentration. At each level, solutions were prepared in triplicate and applied to the plate assay described above. The recovery percentage of fluconazole was determined. In addition, the bioassay results were compared to a second known method (HPLC-UV).

\section{HPLC assay for fluconazole}

The HPLC analyses were carried out on a Agilent 1200 system (Santa Clara, CA, USA), composed of a quaternary pump, an auto sampler, a photodiode array detector (DAD) and HP ChemStation software. The chromatographic conditions employed were those described by Porta et al. (2005). The column used was a reversed-phase $C_{18}$ $(150 \times 4.6 \mathrm{~mm}$ I.D.; $5 \mu \mathrm{m}$ particle size) from ACE (Aberdeen, Scotland), at $30^{\circ} \mathrm{C}$. UV-photodiode array detection was performed at $260 \mathrm{~nm}$. The mobile phase was composed of acetonitrile and water (22:78), at a flow rate of $1.0 \mathrm{~mL} / \mathrm{min}$. The injection volume was $20 \mu \mathrm{L}$.

Approximately $25 \mathrm{mg}$ of fluconazole reference standard were accurately weighed in a volumetric flask of $50 \mathrm{ml}$ and dissolved in mobile phase. The flask volume was adjusted to $50 \mathrm{ml}$ with the same solvent. The sample solutions were prepared by weighing a portion of the capsule's powder, equivalent to about $25 \mathrm{mg}$ of fluconazole, and dissolving in mobile phase, obtaining a $500 \mu \mathrm{g} / \mathrm{mL}$ solution. All solutions were filtered through $0.45 \mu \mathrm{m}$ membranes before injection.

\section{Analysis of fluconazole capsules}

Four commercial samples of fluconazole capsules were analyzed using both the developed and validated mi- 
crobiological method and the HPLC method. The content results obtained by both methods were compared and the agreement between them was evaluated by the Pearson coefficient $(r)$.

\section{RESULTS AND DISCUSSION}

\section{Method development}

In this study we developed and validated a bioassay to determine fluconazole potency in capsules. The standardization of experimental conditions is crucial to obtain reliable and reproducible results. In spite of achieving adequate results, the lack of this standardization is clearly detectable in previous studies involving potency determination of antifungals, since each paper describes a different way of performing the tests. Firstly, the presence of a base layer without the inocula provided easier-to-measure inhibition zones. The described incubation temperatures were $30^{\circ} \mathrm{C}$ (Espinel-Ingroff et al., 1977; Odds et al., 1999), $32{ }^{\circ} \mathrm{C}$ (Purangioti et al., 1999), $35^{\circ} \mathrm{C}$ (Pascual et al., 2007) and $37^{\circ} \mathrm{C}$ (Law et al., 1994; Perea et al., 2000). The temperatures tested in the present paper $\left(28^{\circ} \mathrm{C}\right.$ and 37 ${ }^{\circ} \mathrm{C}$ ) did not yield different results, revealing that both can be used in the experiments. Published incubation times varied from $14 \mathrm{~h}$ (Pascual et al., 2007) to $24 \mathrm{~h}$ (Odds et al., 1999). The incubation time tested in our study ( $24 \mathrm{~h}$ ) was adequate to provide sufficient yeast growth and regular inhibition zones. This was not observed when the plates were incubated for $36 \mathrm{~h}$, which provided lower zones and culminated in significantly reduced concentrations (probably due to the more prominent yeast growth) which were not well correlated to the HPLC assay (data not shown).

A large number of strains have also been used as test organisms: Candida kefyr 706 (Garcia-Hermoso et al., 1995), Candida kefyr ATCC46764 (Perea et al., 2000), Candida albicans DSY1024 (Marchetti et al., 2001), Candida albicans ATCC95020 (Pascual et al., 2007) and Sacharomyces cerevisiae ATCC2601 (Adams, 2006). The strain C. albicans ATCC 18804 used in this work was considered to be adequate for fluconazole testing. In addition, it would be very helpful if researchers and industries used the same strain to perform antifungal determination so as to improve test standardization. The inocula concentration of $1-5 \times 10^{5} \mathrm{CFU} / \mathrm{mL}$ provided the best visualization of the inhibition zones compared to the inocula with $10^{3}$ and $10^{4} \mathrm{CFU} / \mathrm{mL}$, for which zones were not clearly delineated.

In our study design, we used six wells per plate (as depicted in Figure 1), which make possible lower deviations due to the correction of the inhibition zone values by a standard concentration (R). Other researchers have used larger plates in which 16, 36 or even 38 wells were made (Rex et al., 1991; Perea et al., 2000; Marchetti et al., 2001; Pascual et al., 2007). However, a large number of wells on a single plate makes performing the assay and the measurements of the inhibition zones more difficult. Furthermore, the excessive manipulation of each plate increases the possibility of undesirable contamination.

\section{Bioassay}

The inhibition zones were clearly delineated by using optimized testing conditions. Triplicate wells gave the same zone diameters within $1 \mathrm{~mm}$. The average of the corrected inhibition zones values for standard concentrations were $16.61 \mathrm{~mm}\left(\mathrm{~S}_{1}\right), 13.78 \mathrm{~mm}\left(\mathrm{~S}_{2}\right), 10.72 \mathrm{~mm}(\mathrm{R})$, $8.07 \mathrm{~mm}\left(\mathrm{~S}_{4}\right)$ and $5.28 \mathrm{~mm}\left(\mathrm{~S}_{5}\right)$. Calibration curves were plotted and the $r^{2}$ value was $>0.9990$. DMSO, at the final concentration, did not influence the $C$. albicans ATCC 18804 growth.

\section{Validation of bioassay}

A good linear relationship $\left(r^{2}=0.9995\right)$ was found between the fluconazole concentrations and growth inhibition zone diameter, in the assayed range. The regression analysis data are shown in Table I. The representative linear equation for fluconazole was $9.429 x+9.869$. The low R.S.D. value (1.04\%) indicated the precision of the calibration curve.

TABLE I - Overview of the linearity data obtained for fluconazole

\begin{tabular}{lc}
\hline Parameters & Regression analysis results \\
\hline Regression coefficient & 0.9995 \\
Slope \pm standard deviation & $9.429 \pm 0.118$ \\
Intercept \pm standard deviation & $-9.869 \pm 0.264$ \\
Relative standard deviation $(\%)$ & 1.04 \\
Concentration range $(\mu \mathrm{g} / \mathrm{ml})$ & $39.06-625.00$ \\
Number of points & 5 \\
\hline
\end{tabular}

Precision was expressed as relative standard deviation (R.S.D.). In the intra-day precision assay $(n=6)$, the mean content of fluconazole was $95.8 \%$ (R.S.D. $=4.0 \%$ ). For the inter-day precision $(n=12)$, the obtained mean was $96.8 \%$ (R.S.D. $=4.5 \%$ ). The obtained R.S.D. values confirmed the adequate precision of the method.

Accuracy was investigated by means of a standard addition experiment, at three concentration levels, in triplicate $(n=9)$. The recovery percentages varied from $101.5 \%$ to $104.4 \%$ (Table II). The mean recovery of 
$102.9 \%$ assured accuracy of the method. In addition, an adequate correlation with HPLC-UV method was obtained, as depicted in Table III.

TABLE II - Recovery of fluconazole in a standard addition experiment for accuracy evaluation

\begin{tabular}{lccc}
\hline Sample & $\begin{array}{c}\text { Added } \\
(\mu \mathrm{g} / \mathrm{mL})\end{array}$ & $\begin{array}{c}\text { Found } \\
(\mu \mathrm{g} / \mathrm{mL})^{*}\end{array}$ & $\%$ \\
\hline 1 & 39.06 & 40.78 & 104.4 \\
2 & 117.18 & 118.95 & 101.5 \\
3 & 195.30 & 200.99 & 102.9 \\
\hline
\end{tabular}

* average of three determinations

TABLE III - Fluconazole contents in capsule samples obtained by bioassay and HPLC methods

\begin{tabular}{lcc}
\hline \multirow{2}{*}{ Samples } & \multicolumn{2}{c}{ Fluconazole content (\%) } \\
& Bioassay & HPLC \\
\hline 1 & 103.9 & 99.1 \\
2 & 95.6 & 90.7 \\
3 & 95.5 & 90.7 \\
4 & 103.2 & 100.3 \\
\hline
\end{tabular}

\section{HPLC assay}

Samples of four commercial fluconazole $150 \mathrm{mg}$ capsules were quantified in triplicate by HPLC. The obtained chromatogram (Figure 2) shows a symmetrical peak, with a tailing factor of 1.09 and retention time of
$4.44 \mathrm{~min}$. The fluconazole contents in each sample are presented in Table III.

\section{Correlation of bioassay results and HPLC}

The correlation between both methods was evaluated. Figure 3 demonstrates the high agreement regarding the zone inhibition of the bioassay and the peak area of the HPLC method, in five different concentrations $(r=0.9950)$. The contents of fluconazole determined by both methods, for four capsule samples, showed strong correlation, indicated by Pearson's correlation coefficient value $(r=0.9884)$.

The data in Table III indicate higher contents of fluconazole determined by bioassay in comparison to the concentrations assayed by the HPLC method. This observed deviation may be due to the considerable differences between the two distinct methods, such as experimental conditions and detection techniques. In addition, bioassays can reveal subtle changes not demonstrable by chemical methods. However, the contents of fluconazole determined by both methods showed a strong correlation $(r=0.9884)$, which is clear evidence of the correspondence in the results. Similar results were found by Warnock (1988) when comparing bioassay and HPLC for determination of itraconazole.

The bioassay, as presented, is suitable for both research and pharmaceutical industry laboratories. The major advantage of the bioassay is its low cost and relative simplicity; it is easy to perform and requires no special equipment (Rex et al., 1991; Perea et al., 2000). It is interesting to note that in some studies involving bioassay for fluconazole in

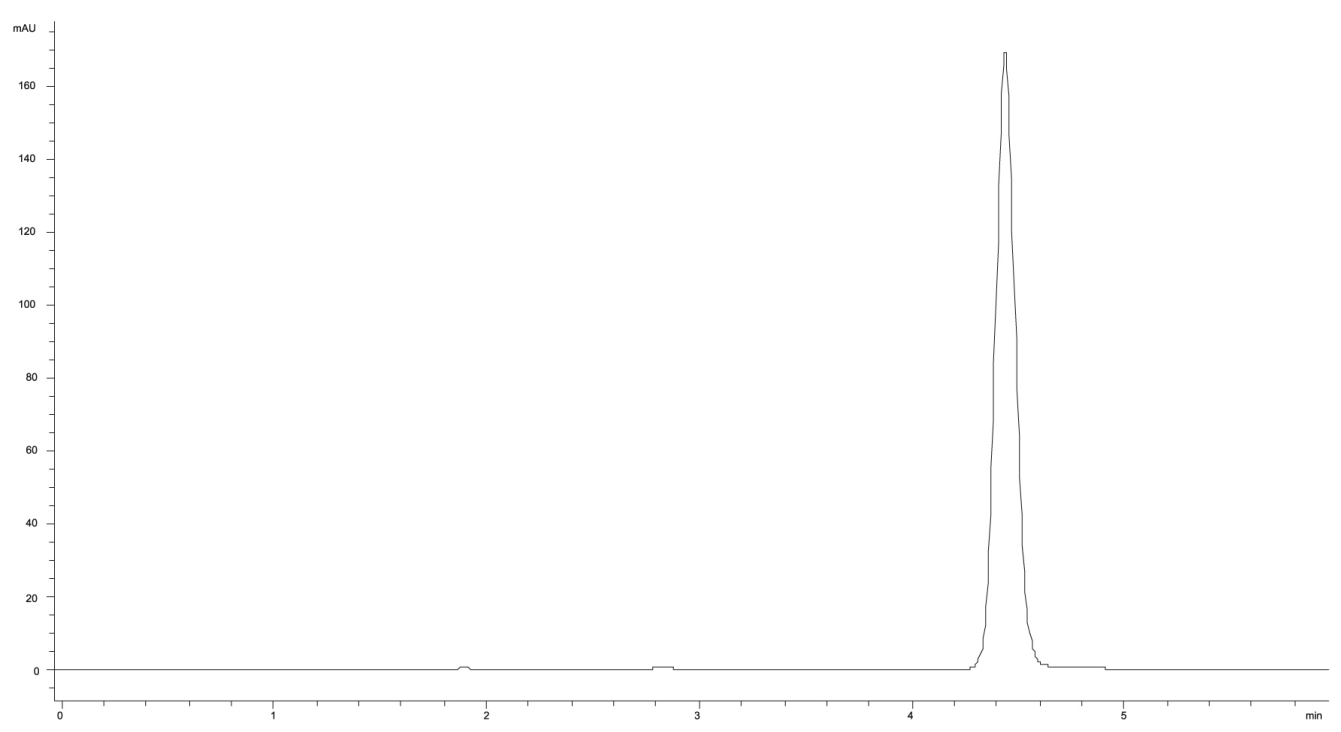

FIGURE 2 - Chromatogram obtained with acetonitrile:water (22:78), using an ACE C18 column $(250 \times 4.6 \mathrm{~mm}$ I.D.; $5 \mu \mathrm{m}$ particle size), at $30^{\circ} \mathrm{C}$, detection at $260 \mathrm{~nm}$. Retention time of fluconazole peak was $4.44 \mathrm{~min}$. 


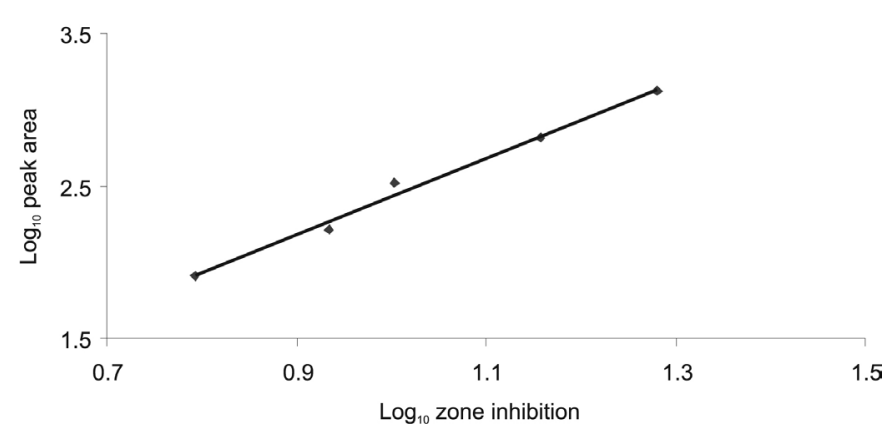

FIGURE 3 - Correlation between HPLC and bioassay: The figure demonstrates the agreement between the responses of the two tested methods $(r=0.9950)$.

plasma and sera, the $r^{2}$ values were lower than the value found in the present paper (Rex et al., 1991; Hüsewede, Dermoumi, 1996). In spite of this slight difference, our results showed bioassay to be reliable, which may encourage other authors and the pharmaceutical industry to perform it for fluconazole, concomitantly with the HPLC method. This is an important step for potency verification of antifungals, even though this kind of test is not present in official pharmacopoeias (Farmacopéia Brasileira, 1988; British Pharmacopoeia, 2007; The United States Pharmacopoeia, 2007). For antibacterial drugs, pharmacopoeias recommend the performing of both HPLC and bioassays, as the tests are complementary to each other.

Bioassays play an essential role in manufacturing and quality control of antibiotic medicines (Salgado et al., 2006). Therefore, the method reported here represents a simple and low cost assay to quantify fluconazole in capsules. The potential of adapting this method for use with other azole antifungals warrants further investigation.

In conclusion, the bioassay for the determination of fluconazole in capsules proved reliable when performed using an inoculum of $1-5 \times 10^{5} \mathrm{CFU} / \mathrm{mL}$ of $C$. albicans ATCC 18804 and an incubation time of $24 \mathrm{~h}$, at $28^{\circ} \mathrm{C}$ or $37^{\circ} \mathrm{C}$.

\section{REFERENCES}

ABDEL-MOETY, E. M.; KHATTAB, F. I.; KELANI, K. M.; ABOUAL-ALAMEIN, A. M. Chromatographic determination of clotrimazole, ketoconazole and fluconazole in pharmaceutical formulations. Farmaco, v.57, p.931-938, 2002.

ADAMS, A. I. H.; STEPPE, M.; FRÖEHLICH, P. E.; BERGOLD, A. M. Comparison of microbiological and UV-spectrophotometric assays for determination of voriconazole in tablets. J. AOAC Int., v.89, p.960-965, 1996.
BRITISH Pharmacopoeia. London: Her Majesty's Stationary Office, 2007. p.835-836

CLINICAL AND LABORATORY STANDARD INSTITUTE (CLSI). M27A2: Reference method for broth dilution antifungal susceptibility testing of yeasts. Approved standard. 2.ed. Wayne: Clinical and Laboratory Standards Institute, 2002. p.1-26.

CLINICALAND LABORATORY STANDARDS INSTITUTE (CLSI). Reference method for broth dilution antifungal susceptibility testing of filamentous fungi. Wayne: Clinical and Laboratory Standards Institute, 2002. (Approved standard M38-A).

COHEN, L. G.; DIBIASO, A.; LISCO, S. J.; HURFORD, W. E. Fluconazole serum concentration and pharmacokinetics in an obese patient. Pharmacotherapy, v.17, p.1023-1026, 1997.

ESPINEL-INGROF, A.; SHADOMY, S.; FISCHER, J. F. Bioassay for miconazole. Antimicrob. Agents Chemother, v.11, p.365-368, 1977.

FARMACOÉIA Brasileira. 4.ed. Atheneu: São Paulo, 1988. p.287.1-287.2.

FIGUEIREDO, V. T.; SANTOS, D. A.; RESENDE, M. A.; HAMDAN, J. S. Identification and in vitro antifungal susceptibility testing of 200 clinical isolates of Candida spp. responsible for fingernail infections. Mycopathol., v.164, p.27-33, 2007.

GARCIA-HERMOSO, D.; DROMER, F.; IMPROVISIS, L.; PROVOST, F.; DUPONT, B. Fluconazole concentrations in saliva from AIDS patients with oropharyngeal candidosis refractory to treatment with fluconazole. Antimicrob. Agents Chemother., v.39, p.656-660, 1995.

HARRIS, S. C.; WALLACE, J. E.; FOULDS, G.; RINALDI, M. G. Assay of fluconazole by megabore capillary gasliquid chromatography with nitrogen-selective detection. Antimicrob. Agents Chemother, v.33, p.714-716, 1989.

HOSTETLER, J. S.; HEYKANTS, J.; CLEMONS, K. V.; WOESTENBORGHS, R.; HANSON, L. H.; STEVENS, D. A. Discrepancies in bioassay and chromatograph determinations explained by metabolism of itraconazole to hydroxyitraconazole: studies of interpatient variations in concentrations. Antimicrob. Agents Chemother, v.37, p.2224-2227, 1993. 
HÜLSEWEDE, J. W.; DERMOUMI, H. Serum level determination of fluconazole by high-performance liquid chromatography and bioassay. Zentralbl. Bakteriol., v.283, p.492-496, 1996.

KEEVIL, B. G.; NEWMAN, S.; LOCKHART, S.; HOWARD, S. J.; MOORE, C. B.; DENNING, D. W. Validation of an assay for voriconazole in serum samples using liquid chromatograph-tandem mass spectrometry. Ther. Drug Monit., v.26, p.650-657, 1994.

KIM, S. S.; IM, H. T.; KANG, I. M.; LEE, H. S.; LEE, H. W.; CHO, S. H.; KIM, J. B.; LEE, K. T. An optimized analytical method of fluconazole in human plasma by high-performance liquid chromatography with ultraviolet detection and its application to a bioequivalence study. $J$. Chromatogr. B., v.852, p.174-179, 2007.

KOKS, C. H.; MEENHORST, P. L.; HILLEBRAND, M. J.; BULT, A.; BEIJNEN, J. H. Pharmacokinetics of fluconazole in saliva and plasma after administration of an oral suspension and capsules. Antimicrob. Agents Chemother., v.40, p.1935-1937, 1996.

LAW, D.; MOORE, C. B.; DENNING, D. W. Bioassay for serum itraconazole concentrations usin hydroxyitraconazole standards. Antimicrob. Agents Chemother., v.38, p.15611566, 1994.

LIMA, P. M. A.; PRADO, N. D.; SILVA, M. L. M.; DINIZ, R. D. L.; QUEIROZ, K. M.; CÉSAR, I. C.; PIANETTI, G. A.; SANTOS, D. A. Determination of ketoconazole in capsules by HPLC and microbiological assay. J. AOAC Internat., v.92, p.1076-1081, 2009.

MARCHETTI, O.; MAJCHERCZYK, P. A.; GLAUSER, M. P.; BILLE, G.; MOREILLON, P.; SANGLARD, D. Sensitive bioassay for determination of fluconazole concentrations in plasma using a Candida albicans mutant hypersusceptible to azoles. Antimicrob. Agents Chemother, v.45, p.696-700, 2001

MATHY, F. X.; VROMAN, B.; NTIVUNWA, D.; WINNE, A. J. D.; VERBEECK, R. K.; PRÉAT, V. On-line determination of fluconazole in blood an dermal rat microdialysates by microbore high-performance liquid chromatograph. $J$. Chromat. B., v.787, p.323-331, 2003.
MORAES, L.A.; LERNER, F.E.; MORAES, M.E.; MORAES, M.O.; CORSO, G.; DE NUCCI G. Fluconazole bioequivalence study: quantification by tandem mass spectrometry. Ther. Drug Monit., v.21, p.200-207, 1999.

ODDS, F. C.; DUPONT, B.; RINALDI, M. G.; STEVENS, D. A.; WARNOCK, D. W.; WOESTENBORGHS, R. Bioassays for itraconazole blood levels: an interlaboratory collaborative study. J. Antimicrob. Chemother, v.43, p.723727, 1999.

PASCUAL, A.; NIETH, V.; CALANDRA, T.; BILLE, J.; BOLAY, S.; DECOSTERD, L. A.; BUCLIN, T.; MAJCHERCAYK, P. A.; SANGLARD, D.; MARCHETTI, O. Variability of voriconazole plasma levels measured by new high-performance liquid chromatograph and bioassay methods. Antimicrob. Agents Chemother., v.51, p.137- 143, 2007.

PEREA, S.; PENNICK, G. J.; MODAK, A.; FOTHERGILL, A. W.; SUTTON, D. A.; SHEEHAN, D. J.; RINALDI, M. G., Comparison of high-performance liquid chromatographic and microbiological methods for determination of voriconazole levels in plasma. Antimicrob. Agents Chemother., v.44, p.1209-1213, 2000.

PORTA V.; CHANG, K. H.; STORPIRTIS, S. Evaluation of the bioequivalence of capsules containing $150 \mathrm{mg}$ of fluconazole. Int. J. Pharm., v.288, p.81-86, 2005.

PURANJOTI, P.; KASINA, R.; TENJARLA, S. Microbiological and HPLC analysis of miconazole in skin, serum and phasesolubility studies. J. Clin. Pharm. Therap., v.24, p.445-450, 1999.

REX, J. H.; HANSON, L. H.; AMANTEA, M. A.; STEVENS, D. A.; BENNETT, J. E. Standardization of a fluconazole bioassay and correlation of results with those obtained by high-pressure liquid chromatography. Antimicrob. Agents Chemother., v.35, p.846-850, 1991.

SALGADO, H. R. N.; LOPES, C. C. G. O.; LUCCHESI, M. B. B. Microbiological assay for gatifloxacin in pharmaceutical formulations. J. Pharm. Biomed. Anal., v.40, p.443-446, 2006.

UNITED States Pharmacopoeia. 30.ed. Rockville: United States Pharmacopeial Convention, 2007. p.2137-2139 
VALIDATION OF ANALYTICAL PROCEDURES: TEXT AND METHODOLOGY Q2 (R1) - ICH Harmonized Tripartite Guideline. International Conference on Harmonization of Technical Requirements for Registration of Pharmaceuticals for Human Use, 2005. p. 1-13.
WARNOCK, D. W.; TURNER, A.; BURKE, J. Comparison of high performance liquid chromatograph and microbiological methods for determination of itraconazole. J. Antimicrob. Chemother., v.21, p.93-100, 1988.

Received for publication on $24^{\text {th }}$ July 2008. Accepted for publication on $29^{\text {th }}$ January 2009. 